DOI: 10.20472/EFC.2019.011.005

\author{
NATALIA DAVIDSON \\ Graduate School of Economics and Management, Ural Federal University , Russian Federation

\section{OLEG MARIEV} \\ Graduate School of Economics and Management, Ural Federal University , Russian Federation
}

\title{
FACTORS DETERMINING ENTERPRISE LOCATION CHOICE IN RUSSIA
}

\begin{abstract}
:
This paper studies determinants of enterprise location decisions in Russia, such as agglomeration levels, home market potential, transport infrastructure and institutional environment. Results confirm that agglomeration levels and home market potential affect foreign firms' location choice and probability that national firms will work in a city. Urbanization economies and home market potential positively affect location choice; localization economies have an inverted $U$ shape. Estimation shows that foreign enterprises are interested in large demand. Under assumption that there are more innovations in diversified cities and cities with favourable business climate, strategic asset seeking might be present. The study confirms negative impact of regional business environment risks on foreign firms' location choice. Results will be useful for regional policy aimed at business development and attracting foreign direct investment.
\end{abstract}

\section{Keywords:}

enterprise location choice, cities, agglomeration economies, home market potential, business environment, foreign direct investment, Russia

JEL Classification: $012, R 12, F 21$ 


\section{Introduction}

Enterprise location choice has both economic and social meaning, being closely linked to availability of jobs and opportunities for personal development. Regions and cities compete for financial and human resources, their success being dependent on firms' location choices. This issue is especially relevant for Russia, keeping in mind its comparatively low population density, large territory and spatial inequalities.

Our objective is to reveal characteristics of cities and regions that make them attractive for enterprises. Of special interest are those characteristics, which can be affected by regional policy measures.

Our hypotheses are the following. Firstly, we assume that firms choose cities where they will have a better market access, i.e. cities with a relatively large market size of their own and with relatively less costly access to the other cities with large market size (Krugman, 1980). Secondly, it can be assumed that firms choose cities where resources are available under lower prices. Besides, it is assumed that firms find attractive the cities where other firms belonging to the same industry or to various industries work. We also assume that infrastructure and business climate positively affect cities' attractiveness. Finally, we check the hypothesis that firms with foreign investments react stronger on the factors mentioned above. This may be the case because they are more flexible in their location choice.

The paper is organized as follows. The next section is devoted to the review of the existing research. Further methods of econometric analysis are presented. Afterwards data is described. Then results are discussed, and conclusion follows.

\section{Literature review}

Actually, in enterprise location choice agglomeration economies play an important role, as they affect enterprise productivity. This issue is studied within New Economic Geography (Krugman, 1991). Marshall (1920) assumed that among the reasons behind industrial concentration were 'the mysteries of trade'. Agglomeration economies in the city are associated with concentration of similar firms (localization or specialization) or of firms belonging to various industries (diversity interrelated with urbanization). Agglomeration economies are based on three principal mechanisms (microfoundations): sharing, matching and learning (Duranton, Puga, 2004). For instance, 'learning mechanisms' are mainly a source of diversity economies. The results of the existing research are mixed, while there is some evidence, also for transition countries, of positive agglomeration externalities (Beaudry, Schifaerova, 2009).

Theories of foreign direct investment (FDI) shed some light on enterprise location choice. Indeed, strategies of multinational corporations that make decisions concerning FDI can be divided into traditional strategies (resource seeking, market seeking, asset seeking and efficiency seeking) and complex strategies pursued by many firms nowadays 
(Andreff, 2003; Dunning, 1993). Pursuit of a particular strategy is associated with characteristics that make countries or regions attractive for the firms. Numerous empirical studies are devoted to FDI. Concerning location choice of enterprises with FDI in Russia, authors point out such determinants as presence of oil and gas, agglomeration externalities in a region, the level of industrial development, market size and advantages of large cities, advantages of transit region, and protection of investors by regional legislation (Gonchar, Marek, 2014; Ledyaeva, Karhunen, Kosonen, 2010).

While many papers analyze location of enterprises with foreign direct investment, we extend the analysis by considering both foreign and national enterprises. Studying the impact of economic activity concentration on enterprise location choice, we distinguish between localization levels on one hand and diversity (and urbanization) levels on the other hand. We analyze location choice on a city level taking regional characteristics into consideration. The next section is devoted to the methods used in our study.

\section{Methods of analysis}

It is assumed, that firms choose locations where they can earn the highest profits. Estimation is based on the profit equation; conditional logit model is used to estimate the parameters of the profit equation, i.e. the location choice of enterprises (MacFadden, 1974; Head, Mayer, 2004). The dependent variable is a city where an enterprise chooses to locate (Combes et al., 2008). Enterprises make the decisions in sequential manner, and some market congestion arises. Firms are attracted to the region ${ }^{1}$ with the highest profits; it leads to increase in competition in this region and to decrease in market potential for each firm. On the other hand, demand increases leading to increase in the market potential. If real market potential decreases below a certain point, firms start choosing the other regions. Profits are analyzed based on the equation:

$U_{r}=\ln A_{r}+\frac{1}{\sigma-1} \ln R M P_{r}-\ln C P_{r}$,

where $A_{r}$ - total factor productivity in the region $\mathrm{r} ; C P_{r}$ - cost price for each firm, which accounts for wage and composite input price. There is also a random component specific to firm-region pairs, $\varepsilon_{r}$. Its distribution function determines functional form of probability of location choice. The equation with firm-specific random component looks like this:

$\bar{U}_{r}=\ln A_{r}+\frac{1}{\sigma-1} \ln R M P_{r}-\ln C P_{r}+\varepsilon_{r}$.

The probability that an enterprise will chose region $r$ is reflected in the following expression:

$\beta x_{i r}+\varepsilon_{i r}$

${ }^{1}$ Here analysis is carried out on a city level; the term 'region' is used in general sense. 
The probability of location in region $r$ can be expressed with the conditional logit model (Ledyaeva, 2010):

$$
P_{i r}=P\left(y_{i}=r \mid x_{i}\right)=P\left(\beta x_{i r}+\varepsilon_{i r} \geq \max _{s \in R_{i}, s \neq r}\left(\beta x_{i s}+\varepsilon_{i s}\right)\right)=\frac{\exp \left(\beta x_{i r}\right)}{\sum_{s} \exp \left(\beta x_{i s}\right)}=\frac{\exp U_{r}}{\sum_{s} \exp U_{s}}
$$

The logit model makes possible estimation of parameters of the profit equation $U_{r}$ using the maximum likelihood method (Combes et al., 2008). The firms' actual location choices reveal the effects of the variables in the equation $U_{r}$. The observations of regional characteristics allow sorting regions based on their potential profits.

Agglomeration indexes are calculated based on enterprise revenue (Vorobyev et al., 2014). Total factor productivity is considered as a function of localization, diversity and urbanization levels in the cities (Rosenthal, Strange, 2003), human capital, regional transport infrastructure and business climate.

Market potential measures accessibility of various regions from the market $\mathrm{r}: M P_{r} \equiv \sum_{s} \frac{Y_{s}}{d_{r s}}$, where $d_{r s}$ - is the distance between $r$ and $s$. Applying this approach we receive the sum of incomes weighted with inverse distance.

The following econometric model is estimated to determine enterprise location choice for a city:

$$
y_{i j t}^{z}=\ln A_{i j t}^{z}+\beta \ln H M P_{i t}^{z}-\alpha \ln c p+\varepsilon_{i j t}^{z}
$$

where $y_{i j t}^{z}$ - the dependent variable - enterprise location choice for a city. It reflects profit in a city compared to national profit in a certain sector. Index $z$ denotes a city; $j$ - industry; $i$ - firm; $t$ - time period. $\ln A_{i j t}^{z}$ stands for total factor productivity:

$$
A_{i j t}^{z}=f\left(\text { loc }_{i j t}^{z}, \operatorname{div}_{j t}^{z}, \text { urb }_{j t}^{z}, \text { hmp }_{t}^{z}, \text { infrastructure }_{j t}^{z} ; \text { busnenvrisk }_{j t}^{z}\right)
$$

Independent variables reflect factors affecting profit through revenue and costs: agglomeration economies, potential demand, resource availability and costs, location advantages and infrastructure.

To take into account costs and quality of labor, city average wages are used. An alternative variable to reflect quality of labour would be educational level of labor force (share of the workforce with higher education or with at least medium level of professional education). However, this formal measure would not reveal the quality of education, therefore wage might be a better indicator. Transportation costs are reflected in distance component of home market potential and with automobile and railroad density. Following Ledyaeva (2010) we include an institutional variable into the model - regional business 
environment risks. Enterprise fixed effects were applied. In the next section, data and variables are discussed.

\section{Data and variables}

Research is based on the SPARK-Interfax enterprise level data augmented with Rosstat regional and city data, and with regional level indexes provided by the Analytical Agency 'Expert'. The sample includes firms belonging to manufacturing tradable industries. Data for the year 2007 on 8569 firms is used.

Firms under consideration are located in 172 cities and towns with population over 100000 people. The cities Moscow and St. Petersburg are excluded from the sample. Chechnya Republic and 4 districts ('okrugs') are also excluded. SPARK-Interfax database contains data on the organizational form, property, the year of foundation, location, revenue, labour, cost price and profit of enterprises. 3-digit OKVED industrial classification is used. Variables are presented in Table 1 below.

Table 1: Definition of variables used in the econometric analysis

\begin{tabular}{|c|c|}
\hline Variable & Definition \\
\hline \multicolumn{2}{|l|}{ Agglomeration indices (city level) } \\
\hline $\ln (l o c)_{t i}^{j z}$ & Localization coefficient \\
\hline $\ln (d i v)_{t}^{z}$ & Diversity coefficient \\
\hline $\ln (\mathrm{urb})_{t}^{j z}$ & Urbanization coefficient \\
\hline \multicolumn{2}{|c|}{ Home market potential (city level): HMPcity $=\ln (u r b p q)_{t}^{z}+\ln (\text { hmpcity })_{t}^{z}$, where } \\
\hline $\ln (\text { hmpcity })_{t}^{z}$ & $\begin{array}{l}\text { Home market potential of cities, surrounding a city } \\
\text { where enterprise is located }\end{array}$ \\
\hline \multicolumn{2}{|l|}{ City characteristics } \\
\hline $\ln$ (wagecity) & $\begin{array}{l}\text { Average monthly nominal wage in a city, payroll, } \\
\text { roubles }\end{array}$ \\
\hline \multicolumn{2}{|l|}{ Regional transport infrastructure } \\
\hline $\ln$ (a_road) & $\begin{array}{l}\text { Regions - density of auto roads, end of year, } \mathrm{km} \text { of } \\
\text { roads per } 1000 \mathrm{sq} \mathrm{km} \text { of territory }\end{array}$ \\
\hline $\ln$ (rw_road). & $\begin{array}{l}\text { Regions - density of railroads, end of year, km of } \\
\text { roads per } 1000 \mathrm{sq} \mathrm{km} \text { of territory }\end{array}$ \\
\hline \multicolumn{2}{|c|}{ Regional investment climate (Indexes by Analytical Agency 'Expert') } \\
\hline In(busnenvrisk) & $\begin{array}{l}\text { Regional business environment risks (regional } \\
\text { investment risks by the Analytical Agency 'Expert') }\end{array}$ \\
\hline
\end{tabular}


We use an indicator for measuring localization suggested by Vorobyev et al. (2014):

$$
\ln \left(\operatorname{loc}_{i t}^{j z}\right)=\ln \left(\text { revenue }_{t}^{j z}-\text { revenue }_{i t}^{j z}+1\right)
$$

where revenue $t_{t}^{j z}$ - the revenue of all firms belonging to an industry $j$ and located in a city $z$; revenue $_{i t}^{j z}$ - revenue of a firm $i$ belonging to an industry $j$ and located in a city $z$. This indicator, although with labor instead of revenue, was applied by Martin et al. (2011).

Concerning diversity, a variation of a new indicator suggested by Vorobyev et al. (2014) is used here, taking into account both variety of industries and inequality among industries:

$$
d i v_{t}^{z}=\frac{\sum_{j=1}^{s}\left(\frac{\text { revenue }_{t}^{j z}}{\text { revenue }_{t}^{z}}\right)^{\frac{1}{s}}-1}{s^{1-\frac{1}{s}}-1},
$$

where revenue $e_{t}^{j z}$ - revenue of all firms belonging to an industry $j$ and located in a city $z$; revenue $_{t}^{z}$ - revenue of all firms in a city $z ; s$ - total number of industries in the country.

This coefficient takes on the value 1 if the distribution of revenue among industries is perfectly equal and the value 0 if all revenue is concentrated in one industry. Diversity is measured on a city level. Diversity is closely linked to the urbanization level: city size, i.e. to the city area, total revenue of business, and to the population density.

Urbanization coefficient measures total revenue of firms belonging to all industries in a city, except for the industry under consideration:

$$
\ln (\mathrm{urb})_{t}^{z}=\ln \left(\text { revenue }_{t}^{z}-\text { revenue }_{t}^{j z}+1\right),
$$

where revenue $e_{t}^{j z}$ - revenue of all firms belonging to an industry $j$ and located in a city $z$; revenue $_{t}^{z}$ - revenue of all firms in a city $z$.

Home market potential of surrounding cities - the sum of total revenues in all industries in cities divided into the distance between the city $i$ and the other city:

$$
\text { hmpcity }_{t}^{Z}=\sum_{z \neq Z} \frac{\text { revenue }_{t}^{z}}{\text { dist }_{Z, z}}
$$

where dist $_{z, z}$ are the physical distances between the cities. Now we turn to discussion of the results. 


\section{Results}

In Table 2 the results of estimating equation (1) are presented; variables affecting total factor productivity are reflected in equation (2). Estimation is done for all enterprises producing tradable goods, as well as for national and foreign firms separately.

Table 2: Enterprise location choice for a city: national and foreign firms Dependent variable: enterprise location choice for a city

\begin{tabular}{|c|c|c|c|}
\hline & $\begin{array}{c}(1) \\
\text { All tradables }\end{array}$ & $\begin{array}{c}\text { (2) } \\
\text { National firms }\end{array}$ & $\begin{array}{c}\text { (3) } \\
\text { Foreign firms }\end{array}$ \\
\hline Idiv & $\begin{array}{l}1.116^{\star * *} \\
(30.63)\end{array}$ & $\begin{array}{l}1.115^{\star \star \star} \\
(29.80)\end{array}$ & $\begin{array}{c}1.137^{\star \star *} \\
(7.09)\end{array}$ \\
\hline Iloc & $\begin{array}{c}0.243^{\star * *} \\
(14.37)\end{array}$ & $\begin{array}{l}0.247^{* \star *} \\
(14.13)\end{array}$ & $\begin{array}{c}0.170^{\star * *} \\
(2.58)\end{array}$ \\
\hline Iloc2 & $\begin{array}{c}-0.00759^{* * *} \\
(-12.30)\end{array}$ & $\begin{array}{c}-0.00770^{* * *} \\
(-12.07)\end{array}$ & $\begin{array}{c}-0.00542^{* *} \\
(-2.21)\end{array}$ \\
\hline Ihmpcity & $\begin{array}{c}0.201^{* \star *} \\
(6.14)\end{array}$ & $\begin{array}{c}0.181^{* * *} \\
(5.38)\end{array}$ & $\begin{array}{c}0.570^{\star * *} \\
(3.85)\end{array}$ \\
\hline lurb & $\begin{array}{c}0.0285 \\
(0.40)\end{array}$ & $\begin{array}{c}0.0441 \\
(0.60)\end{array}$ & $\begin{array}{l}-0.194 \\
(-0.67)\end{array}$ \\
\hline Iwagecity & $\begin{array}{c}-0.291^{* * *} \\
(-5.76)\end{array}$ & $\begin{array}{c}-0.322^{* \star *} \\
(-6.15)\end{array}$ & $\begin{array}{l}0.150 \\
(0.82)\end{array}$ \\
\hline la_road & $\begin{array}{l}-0.132 \\
(-0.39)\end{array}$ & $\begin{array}{c}-0.0599 \\
(-0.17)\end{array}$ & $\begin{array}{l}-1.430 \\
(-1.04)\end{array}$ \\
\hline Irw_road & $\begin{array}{l}2.449 \\
(1.17)\end{array}$ & $\begin{array}{l}2.335 \\
(1.09)\end{array}$ & $\begin{array}{l}6.232 \\
(0.60)\end{array}$ \\
\hline Ibusnenvrisk & $\begin{array}{c}-0.0492 \\
(-0.61)\end{array}$ & $\begin{array}{c}-0.0131 \\
(-0.16)\end{array}$ & $\begin{array}{l}-0.471^{*} \\
(-1.77)\end{array}$ \\
\hline $\begin{array}{l}N \\
\text { adj. } R^{2}\end{array}$ & 940100 & 890172 & 49928 \\
\hline
\end{tabular}

Results show significance of agglomeration effects, both for national and foreign firms. Indexes are interpreted according to the approach by Head and Mayer (2004). The signs and shape of agglomeration effects are robust to changes of the sample. 
In line with the hypotheses formulated in introduction, diversity level and home market potential have positive effect and are significant. Home market potential was expected to be significant based on the existing theoretical and empirical literature (Krugman, 1991; Head and Mayer, 2004). Indeed, firms are interested to be located in a city with large demand. Moreover, the shorter is the distance to the other cities and towns from this particular city, the stronger is motivation to be located in this city.

Coefficients of localization variables reflect theoretically and empirically proven 'inverted $U$ shape' of agglomeration effects in a city. After a certain level of agglomeration is reached, competition and congestion costs outweigh positive agglomeration effects; among the consequences are additional expenditures faced by the firms. The inverted $U$ shape of localization economies confirms a hypothesis of an inverted U-shape of agglomeration economies, proposed by Mills (1967) and Mirrlees (1972). Mills (1967) points out a possibility of congestion in the city beginning with a certain population density due to transportation costs and costs of housing.

Wage effect is either negative or insignificant, i.e. the issue of higher costs for the firms outweighs a potentially better level of human capital reflected by higher average wages in a city. Business environment risks either negatively affect location decisions or are insignificant. Transport infrastructure variables are insignificant in the specification considered above, which is a counterintuitive result, and possibly arises because present transportation system does not connect many important cities directly.

As for the foreign enterprises, the results can be interpreted based on the concept of multinational firms' strategies within which firms pursue market seeking, asset seeking, efficiency seeking or resource seeking strategies, or combine several of these strategies (Andreff, 2003; Dunning, 1993). While analyzing motivation of foreign firms and the consequences from their presence, we take into account findings existing in the literature that firms participating in FDI tend to be more productive than the other firms (Drapkin, 2010). This may lead to the assumption that host economy could benefit from their presence. However, the issue of foreign firms' impact on the national firms and on the host economy has a number of aspects (Aitken and Harrison, 1999). Estimation shows that foreign firms are interested in large demand, i.e. pursue market seeking strategy. They do not seem to pursue efficiency seeking strategy, as far as lower wages are concerned. Under assumption that there are more innovations in diversified cities and cities with favorable business climate, strategic asset seeking might be present.

\section{Conclusion and policy recommendations}

Research showed that agglomeration levels and home market potential affect foreign firms' location choice and probability that national firms will work in a city. Diversity level and home market potential positively affect location choice, while localization economy has an inverted $U$ form. Results reveal that national firms are attracted by the cities with 
relatively lower wage level, while for the enterprises with foreign direct investment this indicator did not prove to be important. Concerning institutional factors, results confirm negative impact of regional business environment risks on the foreign firms' location choice.

These results will be useful for regional policy aimed at business development and attracting foreign direct investment. Namely, the necessity of creating a favorable business environment is confirmed. Indeed, we see both the impact of the institutional variable and positive externalities from diversity of business activity in the city, as well as positive externalities of concentration within the same industry up to some point. As for the home market potential of a city, it can be increased by improving the access to the other cities and towns, particularly through development of transport infrastructure. Besides, the results shed some light on the strategies of foreign firms and therefore on potential benefits for the Russian economy from their presence. To be more specific, foreign firms are found to be attracted to diversified cities and not to be attracted by lower wages, which can be interpreted as a potential for positive impact on the host economy.

The limitations of the research include the technique of determining location of an enterprise in the city; more precise location method based on zip code can be used in the future. Besides, it would be useful to take into account industrial structure while analyzing firm's location decisions more precisely, as for the firms belonging to various industries results could be different. Moreover, analysis for various types of cities would be useful, as in Russia large differences in terms of economic development exist among cities.

\section{Aknowledgements}

Research was supported by the grant of the Russian Science Foundation № 19-1800262 "Empirical modelling of balanced technological and socioeconomic development in the Russian regions". We are grateful to Hubert Jayet for his valuable comments.

\section{References}

Aitken,B.J., Harrison, A.E. (1999) Do domestic firms benefit from direct foreign investment? Evidence from Venezuela. American Economic Review, Vol. 89, No. 3, pp. 605-618.

Andreff, W. (2003) Les multinationales globales. Paris : Editions La Découverte

Beaudry, C. and Schiffauerova, A. (2009) Who's right, Marshall or Jacobs? The localization versus urbanization debate. Research Policy 38, pp. 318-337.

Boudier-Bensebaa F. (2005) Agglomeration economies and location choice. Foreign direct investment in Hungary. Economics of Transition. 2005, Vol. 13, No. 4, pp. 605-628.

Drapkin, I.M. (2010) International trade, foreign direct investment and agglomeration effects under heterogeneity conditions. Izvestiya Ural'skogo Gosudarstvennogo Universiteta, Seria 3, Social Sciences, (In Russian)

Dunning, J.H. (1993) Multinational enterprises and the global economy, Wokingham: Addison-Wesley. 
Duranton, G. and Puga, D. (2004) Micro-foundations of urban agglomeration economies. In V. Henderson and J. Thisse, eds. Handbook of Urban and Regional Economics. Elsevier, 2004, Vol. 4, pp. 20632117.

Gonchar, K. and Marek, Ph. (2014) The regional distribution of foreign investment in Russia. Are Russians more appealing to multinationals as consumers or as natural resource holders? Economics of Transition. 2014, Vol. 22, No. 4, pp. 605-634.

Head, K. and Mayer, Th. (2004) Market potential and the location of Japanese investment in the European Union. Review of Economics and Statistics. 2004, Vol. 86, pp. 959-972.

Krugman, P. (1980) Scale economies, product differentiation, and the pattern of trade. American Economic Review. 1980. Vol. 70, pp. 950-959.

Krugman, P. (1991) Increasing returns and economic geography. Journal of Political Economy. 1991, Vol. 99, pp. 483-499.

Ledyaeva, S.; Karhunen, P. and Kosonen, R. (2010) Location choice of Chinese, Japanese and the US FDI in Russia: Do cross-country agglomeration effects matter? Nordic Conference in Development Economics.

Marshall, A. (1920) Principles of Economics, $8^{\text {th }}$ edition, London: Macmillan and Co., 1920. Original edition 1890.

Martin P.; Mayer T. and Mayneris F. (2011) Spatial concentration and plant-level productivity in France. Journal of Urban Economics. Vol. 69. pp. 182-195.

McFadden, D. (1974) Conditional logit analysis of qualitative choice behavior, Chapter 4 In P. Zarembka (ed.), Frontiers of Econometrics, New York: Academic Press, 1974.

Mills, E. S. (1967) An aggregative model of resource allocation in a metropolitan area, American Economic Review Papers and Proceedings, Vol. 57, No. 2, pp. 197-210.

Mirrlees, J. A. (1972) The optimum city, Swedish Journal of Economics, Vol. 74, No.1, pp. 114-135.

Rosenthal, S. S. and Strange, W. C. (2003) Geography, industrial organization and agglomeration. Review of Economics and Statistics, 2003, Vol. 85, No. 2, pp. 377-393

Vorobyev P.V.; Kislyak N.V.; Davidson N.B. and Kusnetsov, P.D. (2014) Industrial diversity and concentration in the Russian cities as determinants of economic activity. Vestnik UrFU, Vol. 6, pp. 418. (in Russian) 